\title{
Processing of Methane over the Oxide Catalysts
}

\author{
Kusman Dossumov, Gaukhar Ye. Yergaziyeva, Laura K. Myltykbayeva, and Moldyr M. Telbayeva
}

\begin{abstract}
Catalysis of the supported oxide catalysts in the direction of the methane oxidation reaction is investigated. Modified nickel-containing catalysts studied at the reaction of partial oxidation of methane to synthesis gas. The effect of modifying additives (cerium and lanthanum oxides) on the activity and resistance to coking $\mathrm{NiO} / \gamma-\mathrm{Al}_{2} \mathrm{O}_{3}$ catalyst was defined. The introduction of cerium and lanthanum oxides increases resistance to catalyst coking. Rising of lanthanum modified catalyst activity associated with a decrease in its recovery temperature and increased dispersion of particles of metallic nickel. It is found that the developed $3 \% \mathrm{NiO}+2 \%$ $\mathrm{La}_{2} \mathrm{O}_{3} / \mathrm{\gamma}-\mathrm{Al}_{2} \mathrm{O}_{3}$ catalyst for 250 hours under laboratory conditions $\left(\mathrm{CH}_{4}: \mathrm{O}_{2}=2: 1, \mathrm{~T}_{\mathrm{r}}=750^{\circ} \mathrm{C}\right.$ and $\left.\mathrm{W}=1000 \mathrm{~h}^{-1}\right)$ does not lose its activity. It was determined that the use of a tungsten heteropoly acid as the active phase supported on $\mathrm{Al}_{2} \mathrm{O}_{3}$ can direct the process towards the formation of ethylene.
\end{abstract}

Index Terms-Methane, oxidation, catalyst, ethylene, synthesis gas.

\section{INTRODUCTION}

The catalytic conversion of natural gas into motor fuel components, the raw material for the petrochemical industry and organic synthesis for over 20 years is the subject of intensive research are driven by the problem of reducing the resources of hydrocarbons of petroleum origin [1]. Of particular interest in this respect are the partial oxidation of methane to synthesis gas and an oxidizing dimerization of methane to $\mathrm{C}_{2}$ hydrocarbons [2]-[5].

Syngas is a feedstock for the oxygenates (methanol, dimethyl ether, etc.), as well as for the preparation of liquid and solid hydrocarbons by Fischer-Tropsch synthesis. Hydrogen, which is part of the synthesis gas, is used in a number of large chemical processes (production of ammonia, fuel hydrotreating, hydrocracking of petroleum feedstock, the isomerization of n-alkanes and others).

At the same time, hydrogen can be widely used in the future as an alternative engine fuel [6]-[8].

$\mathrm{C}_{2}-\mathrm{C}_{4}$ olefins are of considerable interest as a raw material for industrial organic synthesis, which are widely used for the preparation of polymer materials, plastics, alcohols, esters, carboxylic acids, components of motor fuels, and others.

Ethylene production ranks first in terms of production among basic petrochemicals. On its basis produced the majority of organic synthesis products and polymer

Manuscript received February 10, 2016; revised July 6, 2016. This manuscript «Processing of methane over oxide catalysts» was supported in part by the Ministry of Education and Science of the Republic of Kazakhstan.

The authors are with the Institute of Combustion Problems, 050012 , Bogenbai Batyr Str., 172, Almaty, Kazakhstan (e-mail: dossumov50@mail.ru, ergazieva_g@mail.ru, laura.kaden@mail.ru, telbaeva.moldir@yandex.kz). materials such as polyethylene, polyvinyl chloride, polystyrene, ethylene oxide, ethylene glycol, synthetic ethyl alcohol and al.

For countries with large reserves of cheap natural gas, the practical implementation of these processes today seems economically justified [9]-[12]. Therefore, the creation of highly efficient, selective and stable catalysts for processing light hydrocarbons to produce valuable products of petrochemical synthesis is an important practical and strategic objective.

We report here on the activity of silicon and aluminum oxides, and a new series of catalysts on the base of $\mathrm{H}_{8}[\mathrm{Si}$ $\left.\left(\mathrm{W}_{2} \mathrm{O}_{7}\right)_{6}\right] \mathrm{nH}_{2} \mathrm{O}$ and $\mathrm{NiO}-\mathrm{La}_{2} \mathrm{O}_{3}$, supported on $\mathrm{SiO}_{2}$ and $\mathrm{Al}_{2} \mathrm{O}_{3}$ to be tested in partial oxidation processes and oxidative dimerization of methane.

\section{MATERIALS AND METHODS}

Experiments to test the catalytic activity of the catalysts developed conducted on an automated flow set to the temperature range $600-850^{\circ} \mathrm{C}$ at atmospheric pressure. This set consists of three main parts - the preparation of the initial gas mixture, the catalyst quartz flow reactor and gas chromatograph for analysis. The reactor is a quartz tube 25 $\mathrm{cm}$ in length and an internal diameter of 9-9.5 mm.

During the experiments, the reactor is placed vertically incoming stream fed into an open top portion and exits through the hole in the bottom of the vial. Control composition and flow rate of the reacting starting compounds, the reactor temperature regulation, the evaporator assays run through software. The reaction products were identified by chromatography on device "Chromos GC-1000" using an absolute calibration method and a thermal conductivity detector. Separation of components was carried out on two columns (length $2 \mathrm{~m}$, internal diameter $3 \mathrm{~mm}$ ) filled with $\mathrm{NaX}$ zeolite and porapak - T, carrier gases - helium and argon.

Determination textural properties of developed catalysts and carriers (specific surface $\left(\mathrm{S}_{\mathrm{sp}}\right)$, pore volume and pore size distribution) were carried out by low-temperature nitrogen adsorption at $77 \mathrm{~K}$ on the automatic equipment BEL Japan Inc and heat argon desorption on device BELSORP-mini II. Before beginning the sample test is produced its degassing consists in heating of the sample in the stationary gas flow at a predetermined temperature to remove from the surface of the test material absorbed gases and vapors. The instrument can examined simultaneously to three samples independently. Pressure sensor - 0.666 Pa / min. Weight of catalyst $2.92 \mathrm{~g}$. Experience time 3 hours. Pressure of saturated vapour $102.19 \mathrm{kPa} . \mathrm{Vm}=30.563 \mathrm{~cm}^{3}$ (STP) $\mathrm{g}^{-1}$. The surface area calculated by a BET equation.

Diffraction data (XRD) were obtained on apparatus Bruker AXSD2 Phaser (LYNXEYE high speed detector) 
powder $\mathrm{x}$-ray BrukerD2 using $\mathrm{CuK} \alpha$ radiation, voltage 30 $\mathrm{kV}$ and current $15 \mathrm{~mA}$. Radiographs were collected in $2^{0}$ angle between $10^{\circ}$ and $90^{\circ}$ with a scan speed of $5^{\circ} / \mathrm{min}$. The average size of the crystallite of the catalyst was evaluated by X-ray diffraction peak of the expansion using Scherrer equation $\mathrm{D}=0.9 \lambda / \beta \cos \theta$, where $\lambda$-wave length of the radiation $(\mathrm{h}=0.154 \mathrm{~nm}) \mathrm{Cu} \mathrm{K \alpha}, \beta$-half-width of the peak, and $\theta$-Bragg diffraction peak angle.

Morphology of surface oxide catalysts was performed by scanning electron microscopy Quanta 200i 3D.

Temperature-programmed reduction (TPR) was performed in a laboratory setting, including the gas preparation system with a tubular reactor furnace and a thermal conductivity detector. Hydrogen reduction was carried out by passing the gas mixture $\left(5 \% \mathrm{H}_{2}\right.$ and $\left.95 \% \mathrm{Ar}\right)$ through a reactor at a rate of $30 \mathrm{ml} / \mathrm{min}$. Linear heating rate was $10^{\circ} \mathrm{C} / \mathrm{min}$. The changing the concentration of hydrogen in the stream was monitored using a thermal conductivity detector.

Quantitative determination of the absorbed hydrogen was performed by calibration, built on the basis of reducing of accurate batches of $\mathrm{NiO}$.

Catalysts were prepared by co capillary wetness impregnation of the support with solutions of nitrates and subsequent drying at $300^{\circ} \mathrm{C}(2 \mathrm{~h})$ and calcination at $500^{\circ} \mathrm{C}$ for three hours.

\section{RESULTS AND DISCUSSION}

Known from the literature [13]-[15] that the active phase for the production of synthesis gas by partial oxidation of methane is the nickel oxide.

Therefore, were synthesized nickel catalysts, supported on alumina for the production of synthesis gas from methane.

It was studied the effects of nickel oxide contents in the concentration range of 0.05 to $10 \mathrm{wt}$. \% supported on alumina, on the direction of the process. Fig. 1 shows the effect of concentration of the active phase on a support for methane conversion and hydrogen and carbon monoxide yields at a reaction temperature of $750^{\circ} \mathrm{C}$.

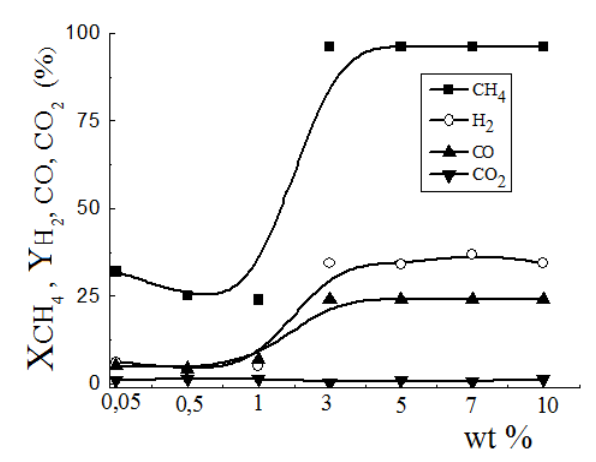

Fig. 1. Effect of nickel oxide concentration on yield of reaction products.

The figure shows that an increase in the nickel content of 0.05 wt. $\%$ to $10 \mathrm{wt}$ \% increases the methane conversion and synthesis gas outputs. Moreover, since the concentration of nickel oxide on the support of $3 \mathrm{wt}$. \% begins a sharp increase of methane conversion and synthesis gas output.
A further increase in the nickel oxide content up to $10 \%$ does not affect the yield of synthesis gas. Over the $3 \% \mathrm{Ni} /$ $\mathrm{\gamma}-\mathrm{Al}_{2} \mathrm{O}_{3}$ catalyst hydrogen yield reaches $34 \%$, mono oxide increases to $24 \%$ and the carbon dioxide yield is reduced to $0.5 \%$, the methane conversion was $96 \%$.

It should be noted that with increasing nickel oxide content of $3 \mathrm{wt}$. \% to $10 \mathrm{wt}$. \% conversion parameters and the output of desired products are not changed. Perhaps this is due to the same active phase composition of the catalyst.

In order to further improve the efficiency of $3 \mathrm{wt} . \% \mathrm{Ni} /$ $\mathrm{\gamma}-\mathrm{Al}_{2} \mathrm{O}_{3}$ in the reaction of partial oxidation of methane, the catalyst was modified with rare earth elements.

Phase intensity reflexes with increasing nickel content of from $3 \%$ to $10 \%$ on the support is not changed substantially.

It is clear from $\mathrm{X}$ - rays, that after the oxidation of methane over these catalysts in the spectrum appears reflex referring to the metal nickel. This change is due to the fact that during the partial oxidation of methane under the influence of the reaction medium $\left(\mathrm{CH}_{4}, \mathrm{H}_{2}, \mathrm{CO}\right)$, some of the nickel oxide is reduced to metallic nickel.
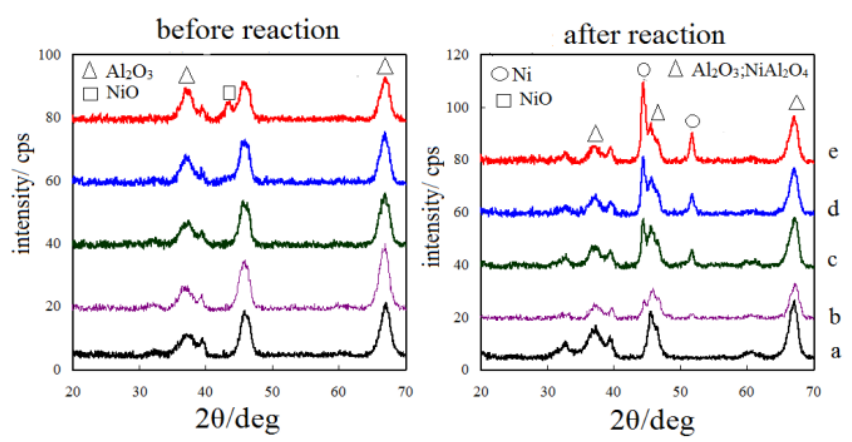

Legend: a- $1 \% \mathrm{Ni}-;$ b- $3 \% \mathrm{Ni}-; \mathrm{c}-5 \% \mathrm{Ni}-; \mathrm{d}-7 \% \mathrm{Ni}-; \mathrm{e}-10 \% \mathrm{Ni} / \gamma-\mathrm{Al}_{2} \mathrm{O}_{3}$ Fig. 2. XRD spectra of $1-10 \% \mathrm{Ni} / \gamma-\mathrm{Al}_{2} \mathrm{O}_{3}$ before and after the reaction.

Based on the review of the literature [16], [17] the oxides of cerium and lanthanum are selected as modifying additives (Fig. 3).

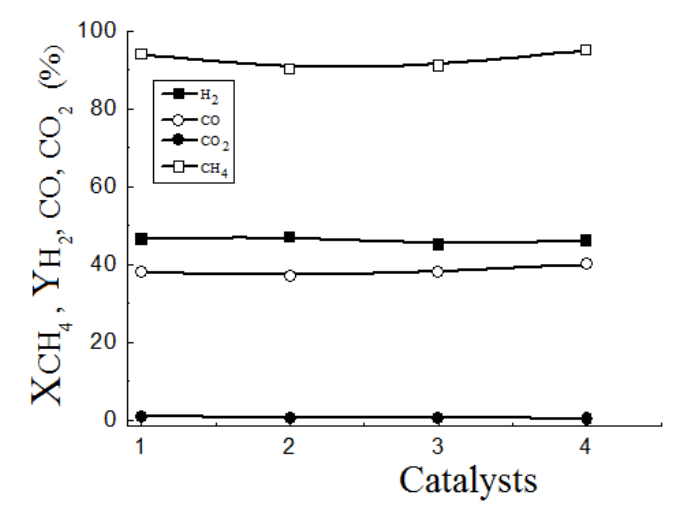

1- $\mathrm{Ni} / \mathrm{Al}_{2} \mathrm{O}_{3} ; 2-\mathrm{Co} / \mathrm{Al}_{2} \mathrm{O}_{3} ; 3-\mathrm{NiSe} / \mathrm{Al}_{2} \mathrm{O}_{3} ; 4-\mathrm{NiLa} / \mathrm{Al}_{2} \mathrm{O}_{3}$

Fig. 3. Effect of modifiers on the catalytic activity of $\mathrm{Ni} / \mathrm{Al}_{2} \mathrm{O}_{3}$ catalyst.

TABLE I: TEXTURAL CHARACTERISTICS OF THE CATALYSTS

\begin{tabular}{|c|c|c|c|}
\hline Catalyst & $\mathrm{S}_{\mathrm{sp} .}, \mathrm{M}^{2} / \mathrm{g}$ & $\begin{array}{c}\text { The spec. pore } \\
\text { vol., } \mathrm{sm}^{3} / \mathrm{g}\end{array}$ & $\begin{array}{c}\text { Average pore } \\
\text { size, } \mathrm{HM}\end{array}$ \\
\hline $\mathrm{Ni} / \mathrm{Al}_{2} \mathrm{O}_{3}$ & 161 & 0.069 & 1.7 \\
\hline $\mathrm{Ni}-\mathrm{Ce} / \mathrm{Al}_{2} \mathrm{O}_{3}$ & 158 & 0.068 & 1.7 \\
\hline $\mathrm{Ni}-\mathrm{La} / \mathrm{Al}_{2} \mathrm{O}_{3}$ & 163 & 0.070 & 1.7 \\
\hline
\end{tabular}

Fig. 3 shows that the best results are obtained at NiLa / $\mathrm{Al}_{2} \mathrm{O}_{3}$ catalyst, where the degree of methane conversion reaches $95 \%$, yields of hydrogen and carbon monoxide - 
46.4 and $40.0 \%$, respectively.

The catalysts were tested by the BET method. The results are shown in Table I. As seen from the table, the texture of the catalysts are not very different from each other.

The specific surface area of nickel catalyst modified with lanthanum oxide is $163 \mathrm{~m}^{2} / \mathrm{g}$.

However, the addition of cerium and lanthanum oxides increases the resistance of a nickel catalyst to coke deposition (Fig. 4).
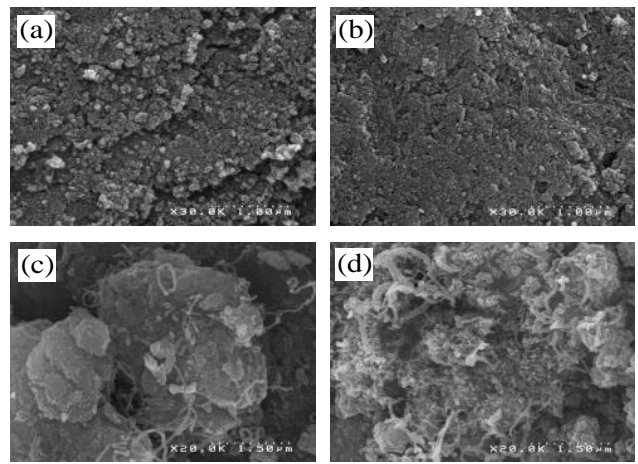

(a) $\mathrm{NiLa} / \gamma-\mathrm{Al}_{2} \mathrm{O}_{3}$, (b) $\mathrm{NiCe} / \gamma-\mathrm{Al}_{2} \mathrm{O}_{3}$,

(c) $\mathrm{NiCo} / \gamma-\mathrm{Al}_{2} \mathrm{O}_{3}$, (d) $\mathrm{Ni} / \gamma-\mathrm{Al}_{2} \mathrm{O}_{3}$

Fig. 4. SEM micrographs.

As seen in Fig. 4, after 30 hours of testing in the oxidation of methane on $\mathrm{Ni} / \gamma-\mathrm{Al}_{2} \mathrm{O}_{3}$ catalyst surface is formed of carbon filaments. Modified by cobalt sample was also subjected to carbonization. While the introduction of cerium oxide and / or lanthanum oxide in the $\mathrm{Ni} / \mathrm{\gamma}-\mathrm{Al}_{2} \mathrm{O}_{3}$ catalyst lowers the carbonization of catalyst.

Oxides of aluminum and silicon have been studied in dimerization of methane to ethylene in the reaction condition: ratio of $\mathrm{CH}_{4}: \mathrm{O}_{2}=2: 1, \mathrm{~W}=2000 \mathrm{~h}^{-1}$ and $\mathrm{T}_{\mathrm{r}}=$ $700-850^{\circ} \mathrm{C}$. The results are shown in Table II.

TABLE II: INFLUENCE OF REACTION TEMPERATURE ON THE ACTIVITY OF OXIDES

\begin{tabular}{|c|c|c|c|c|c|}
\hline \multirow{2}{*}{ Oxides } & \multirow{2}{*}{$\mathrm{T},{ }^{\circ} \mathrm{C}$} & \multicolumn{4}{|c|}{ Concentration, vol. \% } \\
\cline { 3 - 6 } & & $\mathrm{H}_{2}$ & $\mathrm{C}_{2} \mathrm{H}_{4}$ & $\mathrm{CO}$ & $\mathrm{CO}_{2}$ \\
\hline $\mathrm{SiO}_{2}$ & 700 & - & 4.5 & 15.8 & 14.5 \\
\hline & 750 & 0.96 & 4.8 & 17.2 & 13.3 \\
\hline & 800 & 2.5 & 4.5 & 14.3 & 16.3 \\
\hline & 850 & 4.1 & 4.2 & 12.3 & 18.4 \\
\hline $\mathrm{A12O} 3$ & 700 & 1.2 & 4.1 & 6.6 & 26.4 \\
\hline & 750 & 4.5 & 4.2 & 6.9 & 22.6 \\
\hline & 800 & 7.9 & 4.3 & 8.1 & 21.5 \\
\hline
\end{tabular}

As seen from the table, the reaction temperature and the nature of the oxides are not greatly affect the composition of the reaction products. Over the silicon and aluminum oxides formed hydrogen, ethylene, and carbon oxides. On $\mathrm{SiO}_{2}$ with increasing reaction temperature is increasing hydrogen and carbon dioxide concentration. Ethylene and carbon dioxide outputs decrease with increasing temperature passing through a maximum at $750^{\circ} \mathrm{C}$.

On alumina with an increase in reaction temperature is an increase in the yield of hydrogen, carbon monoxide and carbon dioxide concentration decrease from 26.4 to 21.3 vol. \%. Maximum ethylene concentration 4.8 vol. \% is observed at $750 \mathrm{oC}$ on silica.

Further oxides was supported by tungsten heteropoly acid
(HPA) with a concentration of 3 wt. \%. Note that with the application of HPA selectivity to ethylene is increased, the highest yield of ethylene (5.9 vol. \%) is observed over the catalyst $\mathrm{HPA} / \mathrm{Al}_{2} \mathrm{O}_{3}$.

\section{CONCLUSION}

Thus, changing the catalyst composition and the conditions of the oxidation of methane can obtain valuable products as synthesis gas, and ethylene. Supporting of tungsten heteropoly acid on alumina leads to improved selectivity on ethylene.

For the process of partial oxidation of methane to synthesis - gas was developed an effective $3 \% \mathrm{NiO}+2 \%$ $\mathrm{La}_{2} \mathrm{O}_{3} / \mathrm{\gamma}-\mathrm{Al}_{2} \mathrm{O}_{3}$ catalyst. Based on the study of the complex physical and chemical methods (XRD, SEM and BET) found that modification of $\mathrm{NiO} / \mathrm{Al}_{2} \mathrm{O}_{3}$ by lanthanum oxide provides a selective, resistant to carbonization catalyst.

It is shown that during the modifying the catalyst by la2o3 the new phases formed, raised the dispersity of the catalyst and decreased the temperature of reduction of nickel oxide.

It is found that the catalyst of $3 \%$ nio $+2 \%$ la2o3 / yal2o3 for 250 hours under laboratory conditions (ch4: o2 = $2: 1, \operatorname{tr}=750 \mathrm{oc}$ and $\mathrm{w}=1000 \mathrm{~h}-1$ ) does not lose its activity.

Further work will focus on the test of developed catalyst $\left(3 \% \mathrm{NiO}+2 \% \mathrm{La}_{2} \mathrm{O}_{3} / \gamma-\mathrm{Al}_{2} \mathrm{O}_{3}\right)$ in a pilot plant under real conditions of the partial oxidation of methane to synthesis gas.

\section{REFERENCES}

[1] H. A. Nishimo, K. Nakagawa, N. O. Ikenaga, M. Nishitani-Gamo, T Ando, and T. Suziki, "Partial oxidation of methane to synthesis gas over oxidized diamond catalysts," Appl Catal A: General, vol. 264, pp. $65-72,2004$

[2] K. K. Dossumov, G. E. Yergazyieva, L. K. Myltykbayeva, U. Suyunbaev, N. A. Asanov, and A. M. Gyulmaliev, "Oxidation of methane over polyoxide catalysts," Coke and Chemistry, vol. 58, no. 5, pp. 178-183, 2015.

[3] Y. Maegami, F. Iguchi, and H. Yugami, "Promotion of hydrogen using spectrally controlled thermal radiation," Appl Physics Letters, vol. 97 , pp. 1-3, 2010.

[4] T. B. Schädel, M. Duisberg, and O. Deutschmann, "Steam reforming of methane, ethane, propane, butane, and natural gas over a rhodiumbased catalyst," Catal Today, vol. 142, pp. 42-51, 2009.

[5] M. Jose', L. Nieto, B. Solsona, and K. R. Grasselli, and P. Concepcio'n, "Promoted $\mathrm{NiO}$ catalysts for the oxidative dehydrogenation of ethane," Top Catal, vol. 57, pp. 1248-1255, 2014.

[6] M. Mansouri, H. Atashi, F. F. Tabrizi, G. Mansouri, and N. Setareshenas, "Fischer-tropsch synthesis on cobalt-manganese nanocatalyst: Tudies on rate equations and operation conditions," Int $J$ Ind Chem, vol. 5, pp. 1-9, 2014.

[7] K. Dossumov, U. Sujunbaev, A. V. Mironenko, G. Y. Yergaziyeva, and L. K. Myltykbayeva, "Carbon dioxide conversion of methane on polyoxide catalyst," Applied Chemistry and Biotechnology, vol. 2, pp. 20-24, 2014.

[8] A. S. Zola, L. S. da Silva, A. L. Moretti, A. do C. Fraga, E. F. SousaAguiar, and P. A. Arroyo, "Effect of silylation and pupport porosity of $\mathrm{Co} / \mathrm{MCM}-41$ and $\mathrm{Co} / \mathrm{SiO}_{2}$ catalysts in Fischer-Tropsch synthesis," Top Catal, vol. 59, pp. 219-229, 2016.

[9] B. Lemke, C. Roodhouse, N. Glumae, and H. Krier, "Hydrogen synthesis via combustion of fuel-rich natural gas/air mixtures at elevated pressure," Int J Hydrogen Energy, vol. 30, pp. 893-902, 2005.

[10] S. A. Tungatarova, K. Dossumov, and T. S. Baizhumanova, "Production of synthesis-gas on low-percentage Pt-, Ru- and Pt-Ru catalysts," Top Catal, vol. 53, pp. 1285-1288, 2010.

[11] Y. Benguerba, L. Dehimi, M. Virginie, C. Dumas, and B. Ernst, "Modelling of methane dry reforming over $\mathrm{Ni} / \mathrm{Al}_{2} \mathrm{O}_{3}$ catalyst in a 
fixed-bed catalytic reactor," Reac Kinet Mech Cat, vol. 114, pp. 109$119,2015$.

[12] M. Dixit, A. Menon, R. Baruah, A. Bhargav, and S. Sharm, "Oxidative activation of methane on lanthanum oxide and nickellanthanum oxide catalysts," Reac Kinet Mech Cat, vol. 115, pp. 611624, 2015.

[13] B. Valle, B. Aramburu, A. Remiro, J. Bilbao, and A. G. Gayubo, "Effect of calcination/reduction conditions of $\mathrm{Ni}_{1} / \mathrm{La}_{2} \mathrm{O}_{3}-\mathrm{Al}_{2} \mathrm{O}_{3}$ catalyston its activity and stability for hydrogen production by steam reforming of raw bio-oil/ethanol," Appl Catal B: Environmental, vol. 147, pp. 402- 410, 2014.

[14] W. Donphaia, K. Faungnawakij, M. Chareonpanich, and J. Limtrakul, "Effect of Ni-CNTs/mesocellular silica composite catalysts on carbon dioxide reforming of methane," Appl Catal. A: General, vol. 475, pp. 16-26, 2014

[15] H. Ozdemir, M. A. F. Orsuzomer, and M. A. Gurkaynak, "Preparation and characterization of $\mathrm{Ni}$ based catalysts for the catalytic partial oxidation of methane: Effect of support basicity on $\mathrm{H}_{2} / \mathrm{CO}$ ratio and carbon deposition," Int J Hydrogen Energy, vol. 35, pp. $12147-12160,2010$.

[16] S. Y. Foo, C. K. Cheng, T. H. Nguyen, and A. A. Adesina, "Evaluation of lanthanide-group promoters on $\mathrm{Co}-\mathrm{Ni} / \mathrm{Al}_{2} \mathrm{O}_{3}$ catalysts for $\mathrm{CH}_{4}$ dry reforming," J Mol Catal A Chem, vol. 344, pp. 28-36, 2011.

[17] K. Dossumov, G. Y. Yergazyieva, L. K. Myltykbayeva, N. A. Asanov, and E. Z. Ermeshev, "Nickel-lanthanum catalysts for three reforming of methane," in Proc. the Eleventh International Symposium on Heterogeneous Catalysis, Bulgaria, 2015, p. 4.

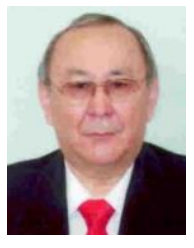

Dossumov Kusman was born in Semipalatinsk, Kazakhstan on February 27, 1950. Since 2000, he has been a professor of chemistry, Almaty, Kazakhstan. In 1996 he got the doctor degree diploma in catalysis, IOCE AS RK, Almaty, Kazakhstan. In 1972 he got the high education diploma KazSU, chemistry.

At 1972-1995 he was leading, senior and junior sci researcher. During 1995-2007 he was the deputy director of D. V. Sokolsky IOCE MES RK, at 2007-2010, general director of D. V. Sokolsky Institute of Organic Catalysis \& Electrochemistry (IOCE) MES RK. Since 2011 until current he is deputy director of CHMA al-Farabi Kaz NU, Almaty, Kazakhstan. His current research interests are catalysis, petrochemistry, ecology.

K. Dossumov got the Georgian medal of IV degree of the International Academy of Reiting «Gold Fortuna», Ukraine in 2005. In 2008, he is a corresponding member of National Engineering Academy of RK, Almaty,
Kazakhstan. In 2011, he is an academician of Kazakhstan's National Academy of Natural Sciences; a member of scientific journals editorship «Combustion \& Plazmochemistry», «Bulletin of al-Faraby KazNU"; «News on Kazakhstan Science». In 2015, he is a member of American Chemical Society ACS, and an associated member of Royal Society of Chemistry UK. In 2016, he is a member of APCBEES.

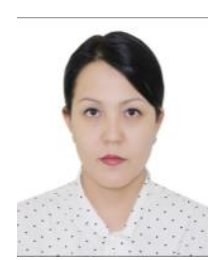

Yergaziyeva Gaukhar Yergaziyevna was born in Alma-Ata on September 27, 1979. In 2002 she got the diploma of master KazNU al-Farabi and in 2011, she got the diploma of candidate of chemical sci, catalysis, Almaty, Kazakhstan. In 2013, she was a leading sci researcher in Institute of Combustion Problems. During 2003-2011, she was a senior, junior sci researcher, engineer of IOCE NAS RK. Her current research interests are catalysis, petrochemistry, ecology.

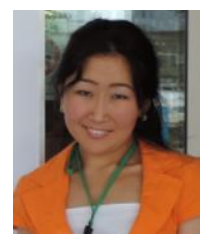

Myltykbayeva Laura Kadenovna was born in Semipalatinsk, Republic of Kazakhstan on May 11, 1988. In 2012, she got diploma of master Abay KazNPU, Almaty, Kazakhstan. In 2012-2015 she studied $\mathrm{PhD}$ doctoral course al-Faraby KazNU, Almaty, Kazakhstan.

She is a junior researcher of Institute of Combustion Problems, Almaty, Kazakhstan. In 2014 she had an internship in Japan during 4 months. Her current research interests are catalysis and ecology.

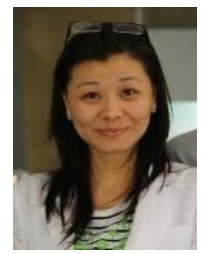

Telbayeva Moldir Muratbekovna was born in Almaty, Republic of Kazakhstan on January 7, 1988. In 2009, she got diploma of bachelor and in 2013 she got diploma of master from al-Farabi KazNU, Almaty, Kazakhstan.

During 2009-2011 she was engineer of Institute of IOCE NAS RK. From 2012 she is a junior researcher of Institute of Combustion problems. Her current research interests include ecology and catalysis. 